\section{TRANSFORMER NOISE}

A PAPER by J. Swaffield (J. Inst. Elec. Eng., 89, Pt. 1, No. 17, May, 1942) reports the main results of an investigation carried out (1935-37) by the British Electrical and Allied Industries Research Association on model cores under controlled conditions to provide fundamental information-on transformer noise. The factors affecting core noise are flux density, magnitude and uniformity of the core clamping pressure, steel quality, lamination thickness, type and thickness of interlaminar insulation, and method of interleaving the laminations. The ranges of design variables covered by the tests were flux density, $8,000-16,000$ lines $/ \mathrm{cm} .{ }^{2}$ or higher; clamping pressure, $0-350 \mathrm{lb} / \mathrm{sq}$. in.; qualities of steel, E.S. stalloy and stalloy; thickness of laminations, 14 and 18 mils; insulation between laminations, insuline, paper and scale only; type of joint, concentrated, distributed and none.

At $50 \mathrm{c} . / \mathrm{s}$. excitation, the noise was found to consist of $100 \mathrm{c} / \mathrm{s}$. harmonics of which the $200 \mathrm{c} . / \mathrm{s}$. and $300 \mathrm{c} . / \mathrm{s}$. components usually predominated; no $50 \mathrm{c} / \mathrm{s}$. harmonics were present. Noiso is associated with the following fundamental sources of vibration : interlaminar fluxes, resulting in vibration of individual laminations; magnetostriction, resulting primarily in core vibration as a whole; forces between turns due to winding currents, resulting primarily in conductor vibration. The effects of the various factors upon emitted noise were found to be those now cited.

Harmonic intensity levels are all funetions of flux density, which greatly influences noise quality and quantity. Clamping affects only the joint noise, which can be determined only by experiment; if it forms an appreciable proportion of the total, joint noise becomes important, as it is penetrating. The effects of joint noise appear to be present mainly in the noise emission at $400 \mathrm{c} . / \mathrm{s}$. and higher frequencies. Joint noise can be reduced greatly by careful core assembly, including interleaving. Very large clamp. ing pressures are unnecessary and it is more important that the clamping should be effective in the region of a joint than large at any particular point. Immersion in oil has a considerable effect in suppressing joint noise. Great reduction in the core vibration combined with reasonable economy is not to be anticipated unless the magnetostriction effect is reduced, and only by a suitable modification in its magnetostrictive property can a change in the type of steel be expected to effect an improvement in noise emission. Thickness of stampings affects only the joint noise and is unimportant. The insulation used between stampings does not appreciably affect the noise. Interleaving, in conjunction with suitable clamping, tends to effect substantial reduction in joint noise. Noise contributed by the coils consists mainly of fundamental tone and is not generally important compared with core noise.

The noise emitted by a transformer is thus due mostly to magnetostriction in the core laminations and to core joints. In large transformers the effect of magnetostriction predominates, but in smaller units the joints may effect substantial modification of the noise eaused by magnetostriction. The main characteristics of magnetostrictive noise can be calculated by determining the form of the vibration it induces in the core and analysing this to obtain a measure of the sound intensity at the various harmonic frequencies. Experiments on model cores showed that results so obtained are representative of the noise actually produced. Improvement can be effected by reducing the flux density, but this is not economical. In order to secure a perfectly quiet transformer both joint noise and magnetostriction noise must be eliminated. As the latter predominates in all but the smallest transformers, little improvement ean be expected by reducing the former.

Since the main investigation was carried out, a series of noise-analysis measurements has been made on a commercial transformer in an oil-filled tank and in air. Apart from joint noise the tests indicated that oil-immersion of the core has little effect on the characteristics of the noise. Both series of harmonic analyses showed remarkable similarities to those given in the report; such results as were obtained all tended to confirm the conclusions reached by the investigator.

\section{APPOINTMENTS VACANT}

Appucations are invited for the following appointments on or before the dates mentioned:

Assistant ChIEF Electrical ENGINERr to the Letchworth Electricity Undertaking-The Chief Electrical Engineer, Electricity Works,
Letchworth (July 2).

ASSISTANT DAIRY BACTERIOT,OGIST-The Bursat, Seale-Hayne Agricultural College, Newton Abbot, Devon (July 4).

EDUCATIONAL PSYCHOLOGIST (MAN OR WOMAN) - The City Education officer, 12 St. Giles Street, Edinburgh 1 (July 4).

LECTURER IN FNGINEERING SUBJECTS-The Principal, Kingston Technical College, Kingston, Surrey (July 4).

FIRst Enginening Assistant in the Waterworks Department of the County Borough of Brighton-The Waterworks Engineer, 12 Bond Street, Brightion (endorsed 'First Engineering Assistant') (July 6).

PRINCIPAL OF THE BATIEY TECHNICAI COLLEGE AND SCHOOL OF ART-The Director of Education and Secretary to the Managers,
Batley Technical College and School of Art, Batley, Yorkshire (July 6). ThanNical Assistant in the Electricity Department of the County Borough of Londonderry-The Town Clerk, Guildhall, Londonderry (July 7).

LECTURER IN ZOOLOGY (MAN OR WOMAN)-The Registrar, University College, Leicester (July 13).

Assistant Darry BaCteriologist-The Principal, Harper Adams Agricultural College, Newport, Shropshire.

WOMAN LECTURER IN GEOGRAPHY-The Principal, Edge Hill Training College, at Bingley, Yorkshire.

\section{REPORTS and other PUBLICATIONS}

(not included in the monthly Books Supplement)

\section{Great Britain and Ireland}

Institution of Gas Engineers. Communication No. 246: 79th Annual Report and Accounts of the Council of the Institution of Gas Engineers to be presented at the 79th Annual General Meeting to be 248: The Gas Industry; Further Considerations on Efficiency and Development. Pp. 68. (London : Institution of Gas Engineers.) [86 Empire Cotton Growing Corporation. Progress Reports from Experiment Stations, Season 1940-1941; Programmes of Experiments, Season 1941-1942. Pp. ii +216. (London : Empire Cotton
Growing Corporation.) 38 .

\section{Other Countries}

Universidad de Buenos Aires: Facultad de Agronomia y Veterinaria. Jornadas Agronómicas y Veterinarias, 1937. Pp. 416. Jornadas Agronomicas y Veterinarias, 1939. Pp. 572. (Buenos Aires: Universidad de Buenos Aires.)

Proceedings of the United States National Museum. Vol. 92, No 3134: The Freda, N. Dak., Meteorite, a Nickel-rich Ataxite. By E. P. Henderson and Stuart H. Perry. Pp. 21-24+4 plates. Vol. 92, No. 3138: A New Stomatopod Crustacean from the West Coast of Mexico. By Steve A. Glassell. Pp. 53-56. (Washington, D.C.: Government Printing Office.)

Imperial College of Tropical Agriculture. Report of the Governing (Trinidad and London: Imperial College of Tropical Agriculture.) [156

Forest Research Institute, Dehra Dun. Indian Forest Leaflet No. 12 : Medicinal Products from Pinus longifolia Iar. By T. P. Ghose and B. S. Varma. Pp. ii +6. (Dehra Dun: Forest Research Institute.) 